(Cytology, Physiology and Psychology) being under the immediate supervision of men eminently fitted for their work.

The course in Cytological Research will be conducted by Professor Watasé, with the assistance of Mr. W. H. Packard. The course is designed for a limited number of students who are prepared to begin investigation. A special problem will be assigned to each member of the class, and methods of dealing with it will be suggested. The laboratory work will be accompanied by a series of lectures on general cytological subjects, designed to give a view of the field of cellular biology as a whole, and at the same time to indicate the bearings of the problems under investigation.

The course in General and Comparative Physiology will be conducted by Dr. Loeb, assisted by Drs. Norman, Lyon and Mathews, and will consist of laboratory work and lectures. The following is a brief outline of the work :

I. The Tropisms of Animals. Galyanotropism, Heliotropism, Geotropism and Compensatory Motions, Chemotropism, Heterotropism in sessile and free forms.

II. Effects of External Influences upon Living Matter (lack of oxygen, acids and alkalies, temperature, etc.).

III. Physiological Morphology. Experiments on Growth and Development, Regeneration and Heteromorphosis.

IV. Comparative Physiology of the Central Nervous System and Comparative Psychology.

V. Comparative Physiology of Digestion.

VI. Comparative Physiology of Secretion.

VII. Micro-chemistry.

In Comparative Psychology, Dr. Edward Thorndike will give a course of lectures on the Sense-powers, Instincts, Habits and Intelligence of Animals, and will direct the work of a few students in this department.

Opportunities for work in Botany are especially inviting. Drs. Davis and Moore, as heads of the department, will have general charge of the laboratory.

The course of lectures in Plant Morphology and Physiology is supplied by such a strong corps, and the subjects are of such scientific importance, that we copy the program in full :

A COURSE OF LECTURES ON PLANT MORPHOLOGY AND PHYSIOLOGY.

First Week, July 5-12.-Erwin F. Smith, 'Bacteria'; D. T. MacDougal, 'Physiological Subjects'; Douglas H. Campbell, 'The Evolution of the Sporophyte in the Archegoniates and Flowering Plants.'

Second Week, July 12-19.-Miss Clara E. Cummings, 'Lichens'; L. M. Underwood, 'The Erolution of the Hepaticx'; Rodney H. True, 'Plants and Poisons.'

Third Week, July 19-26.-H. J. Webber, 'Spermatogenesis, Development of Embryo Sac, and Fecundation in Gymnosperms'; C. O. Townsend, 'Physiology of the Plant Cell.'

Fourth Week, July 26-August 2.-J. M. Macfarlane, 'Plant Irritability'; G. F. Atkinson, 'Higher Fungi.'

Fifth Week, August 2-9.-J. M. Macfarlane, 'Physio-morphology of a Few Angiospermic Orders'; Henry Kraemer, 'The Unorganized Contents of the Cells of Plants.'

Sixth Week, August 9-16.-D. M. Mottier, 'Cytological Studies on the Pollen and Embryo-sac of Angiosperms'; D. P. Penhallow, 'Paleobotany.'

Within the last few years workers at Wood's Holl have derived great profit from the free discussion of various biological methods, facts and theories. During the coming summer there will be three seminars: The Neurological, Biological and Botanical-a series of lectures on Zoological Technique, and the customary course of 'Evening Lectures.' The latter are designed to present the results of research in different lines and departments, in so far as these are of general interest.

There are thirty names on the list of officers of instruction, and fifty-four names on the list of lecturers. In these two lists fully thirty-five educational institutions are represented.

\section{GEOLOGICAL EXPEDITION OF DR. BECKER TO THE PHILIPPINES.}

Dr. Geo. F. BeCKer, the expert economic geologist, who, early last summer, was sent by the Director of the U. S. Geological Survey, under a cooperative arrangement with the War Department, to Manila to make a reconnaissance of the geologic structure and mineral re- 
sources of the Philippines, has been prevented by the uncertainty of the political situation and the state of war there existing from prosecuting these investigations, through no fault, however, of either Admiral Dewey or General Otis, both of whom would ere this have provided the facilities for safe travel about the islands, etc., if it had been possible to do so. From recent advices from the military authorities at Manila, however, it appears that, not content to rest in idleness, Dr. Becker early attached himself to the Bureau of Military Information of the Army, and soon became the right-hand man of Major J. F. Bell, in charge. Official reports and papers that have since passed between Major Bell and the Commanding General, and letters from the officers to Director Walcott, record numerous valuable services rendered by Dr. Becker to the army through the Bureau of Military Information, and also repeated acts of gallantry and soldierly usefulness in action, and accord him high praise for his conduct. $\mathrm{He}$ is repeatedly and strongly complimented by his military superiors, from Major Bell to Generals MacArthur and Otis. The reports, which cover events only to the middle of March, mention no fewer than 14 military reconnaissances and active engagements had with the forces, in all of which Dr. Becker took part.

It has not yet been determined by the Director of the Survey how long Dr. Becker shall remain in the Philippine Islands, but it is believed that he will be able to make some substantial progress with his geologic investigations before he is recalled. Being skilled in rapid field observation, he will be able to advance the work rapidly if once he gets at it. It is not improbable that he is even now doing stratigraphic geology in the Island of Negros, with a view to correlating its structure with that of Cebu. At least, he expressed the hope when he last wrote to Director Walcott, March 1st, of being able to do this in April and after that of going to Cebu and studying the coal deposits.

It is reported that Dr. Becker contemplates returning to America via the Suez Canal and of making a study en route of the great tin deposits at or near Singapore.

MAY 5,1899
CONVERSAZIONE OF THE ROYAL SOCIETY.

THE first Conversazione of the season was held by the Royal society at Burlington House, on May 3d. The guests were received by the President, Lord Lister, and a large number of men of science was present. The following particulars concerning the exhibits, which were of a more strictly scientific character than usual, are taken from the London Times: Professor Arthur Thomson exhibited a model to illustrate how natural curliness of the hair is produced. An exhibit from the Marine Biological Association of Plymouth illustrated methods of feeding of marine animals by means of living and preserved examples. A series of selected animals from the neighborhood of Plymouth was shown, illustrating different methods practiced for securing food. The Association also showed charts illustrating the distribution of the fauna and bottom deposits near the 30-fathom line from the Eddystone grounds to Start Point. Dr. Francisco Moreno, who has done so much for the exploration of Patagonia, exhibited a portion of skin of an extinct ground-sloth from a cavern in southern Patagonia, which has been exciting great interest among naturalists. To Dr. Moreno was also due a fine plaster reproduction of the skeleton of Toxodon platensis, an extinct ungulate quadruped from the Pampa formation, province of Buenos Ayres, Argentina. Dr. Woodward's selection of zoological specimens from Christmas Island, Indian Ocean, collected by Mr. C. W. Andrews, was of special interest, containing, as it did, some remarkable forms of insects, birds, and even rats. Not less interesting was the varied collection of birds, insects, shells, etc., brought home by Dr. H. O. Forbes and Mr. Grant from Sokotra.

Dr. Manson and Surgeon-Major Ross showed microscopes beneath which were displayed specimens of mosquitoes, showing the development of the parasites of malaria in their tissues, and also of the same parasites assuming deadly dimensions in the human tissues.

Among other exhibits were the new element Victorium, of the Yttrium group, one of the latest results of Sir William Crookes's long continued researches in phosphorescent spectra; Mr. Saville-Kent's natural-colpr photographs 